\title{
Living with Progeria
}

\author{
Marjet Stamsnijder \\ From 5th European Conference on Rare Diseases (ECRD 2010) \\ Krakow, Poland. 13-15 May 2010
}

Children with Progeria can be an inspiration to those who meet them.

\section{Mission}

The Progeria Family Circle is a parents' organisation and network that supports European Progeria children and their families in several ways. The objectives are fourfold:

\section{Meetings}

First, the foundation organises annual meetings for all European children and their families. These are important highlights, because of the rarity of the disease children never see other patients. Also for the parents, mutual contact proved very valuable. Meetings are a source of joy in which the children find much selfesteem. Also they have the opportunity to speak with specialist physicians, and to exchange actual information about Progeria.

\section{Information}

As a second objective, the Progeria Family Circle offers parents of European children advice and support where needed. The value of emotional support and assistance of parents with experience is difficult to estimate. We bring family doctors and physiotherapists into contact with specialists in the field of Progeria.

\section{Support}

Progeria families come from different countries with different social, political and religious backgrounds. It is sometimes a big problem for families to give their children enough care. We also look for solutions to individual households to help them as directly as possible. If necessary, we seek financial support, when needed for the welfare of the child.

\section{Medical developments}

The fourth objective focuses on the medical field. The aim is to support better and faster recognition of symptoms and problems in new, but also known patients.

Scientific research and new therapies have made much progress in the past few years. An experimental treatment with Farnesyltransferase inhibitors (FTIS) started in Boston, and European children were offered a different therapy with a combination of statines and aminobiphosfonate in Marseille. The last combination of medication is also now used in Boston.

Published: 19 October 2010

doi:10.1186/1750-1172-5-S1-O9

Cite this article as: Stamsnijder: Living with Progeria . Orphanet Journal of Rare Diseases 2010 5(Suppl 1):O9.
Correspondence: marjet.stamsnijder@gmail.com

Progeria Family Circle, Nude 6, Rhenen 3911 VK, The Netherlands
Submit your next manuscript to BioMed Central and take full advantage of:

- Convenient online submission

- Thorough peer review

- No space constraints or color figure charges

- Immediate publication on acceptance

- Inclusion in PubMed, CAS, Scopus and Google Scholar

- Research which is freely available for redistribution

Submit your manuscript at www.biomedcentral.com/submit 